San Jose State University

SJSU ScholarWorks

Master's Theses

Master's Theses and Graduate Research

1995

\title{
Age determination of steelhead trout (Oncorhynchus mykiss) in microhabitats of a small central California coastal stream using otolith microstructural analysis
}

Lanette D. Davis

San Jose State University

Follow this and additional works at: https://scholarworks.sjsu.edu/etd_theses

\section{Recommended Citation}

Davis, Lanette D., "Age determination of steelhead trout (Oncorhynchus mykiss) in microhabitats of a small central California coastal stream using otolith microstructural analysis" (1995). Master's Theses.

986.

DOI: https://doi.org/10.31979/etd.m7hf-32ft

https://scholarworks.sjsu.edu/etd_theses/986

This Thesis is brought to you for free and open access by the Master's Theses and Graduate Research at SJSU ScholarWorks. It has been accepted for inclusion in Master's Theses by an authorized administrator of SJSU ScholarWorks. For more information, please contact scholarworks@sjsu.edu. 


\section{INFORMATION TO USERS}

This manuscript has been reproduced from the microfilm master. UMI films the text directly from the original or copy submitted. Thus, some thesis and dissertation copies are in typewriter face, while others may be from any type of computer printer.

The quality of this reproduction is dependent upon the quality of the copy submitted. Broken or indistinct print, colored or poor quality illustrations and photographs, print bleedthrough, substandard margins, and improper alignment can adversely affect reproduction.

In the unlikely. event that the author did not send UMI a complete manuscript and there are missing pages, these will be noted. Also, if unauthorized copyright material had to be removed, a note will indicate the deletion.

Oversize materials (e.g., maps, drawings, charts) are reproduced by sectioning the original, beginning at the upper left-hand corner and contiming from left to right in equal sections with small overlaps. Each original is also photographed in one exposure and is inciuded in reduced form at the back of the book.

Photographs included in the original manuscript have been reproduced xerographically in this copy. Higher quality $6^{n} \times 9^{n}$ black and white photographic prints are available for any photographs or illustrations appearing in this copy for an additional charge. Contact UMI directly to order.

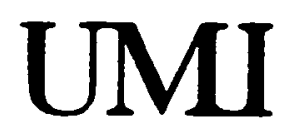

A Bell \& Howell information Company

300 North Zeeb Road. Ann Afbor. M1 48106-1346 USA

$313 ! 761-4700 \quad 800: 521-0600$ 

AGE DETERMINATION OF STEELHEAD TROUT (Oncorhynchus mykiss) IN MICROHABITATS OF A SMALL CENTRAL CALIFORNIA COASTAL STREAM USING OTOLITH MICROSTRUCTURAL ANALYSIS

\author{
A Thesis \\ Presented to \\ The Faculty of the Department of Biology \\ San Jose State University
}

\author{
In Partial Fulfillment \\ of the Requirements for the Degree \\ Master of Science
}

by

Lanette D. Davis

May, 1995 
UMI Number: 1374577

UMI Microform 1374577

Copyright 1995, bY UMI Company. All rights reserved.

This microform edition is protected against unauthorized copying under Title 17, United States Code.

\section{UMI}

300 North zeeb Road

Ann Arbor, MI 48103 
APPROVED FOR THE DEPARTMENT OF BIOLOGY

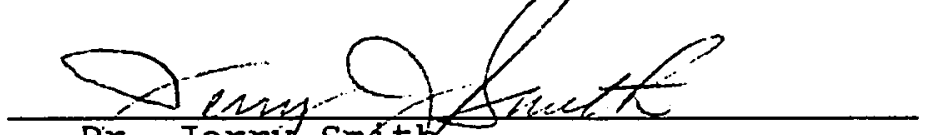
Br. Jerry sivith

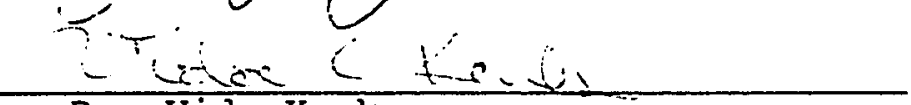
Dr. Vida Kenk

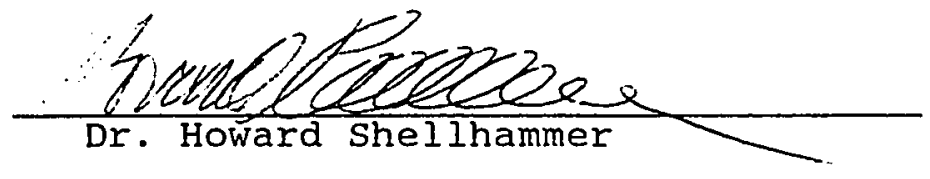

APPROVED FOR THE UNIVERSITY

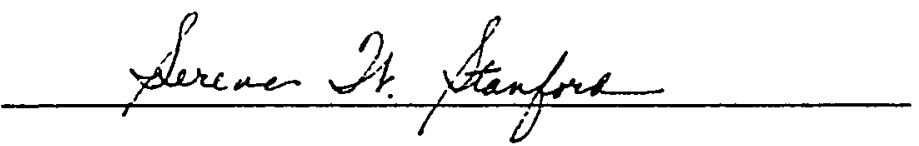


() 1995

Lanette D. Davis

ALL RIGHTS RESERVED 


\begin{abstract}
Age Determination of steelhead Trout (Oncorhynchus mykiss)

in Microhabitats of a small central california coastal

stream Using otolith Microstructural Analysis

by Lanette $D$. Davis
\end{abstract}

In order to examine relationships of size to habitat used and to age in young-of-year steelhead (Oncorhynchus mykiss), I investigated movement, size differences, and age differences in different habitats on waddell creek, Santa cruz County, California. Marked fish did not apparently move among habitats between July/August and October 1993. Steelhead in pools were slightly larger than those in riffles, reflecting either better growth in pools or that larger, more dominant steelhead preferentially used pools during the growing season. Upstream steelhead were significantly smaller than downstream steelhead in both July/August and October. Otolith analysis showed that larger fish emerged from gravels earlier and that downstream fish were probably larger because they were older. No significant difference in fish age was found between habitats at either the upstream or the downstream sites, although small sample size may have prevented detection of small differences. Age and size analysis indicated little growth after July. 


\section{ACRNOWLEDGMENTS}

I especially thank my major professor, Dr. Jerry $\mathrm{J}$. Smith, who got me involved in fisheries and aquatic ecology. His concern and enthusiasm for his profession is at the root of my love for fisheries. Thank you also to my other two committee members, Dr. Howard Shellhammer and Dr. Vida Kenk, who took time out of their busy schedules to evaluate this thesis and who gave me support and encouragement throughout my education at San Jose State University.

Special thanks to my best friend and partner, John stanziano, whose encouragement kept me going on my project and whose expert help in the field and ideas in the lab made the completion of this thesis possible. Also thanks to my family, Mom, Gram, Lorrene, Michael, and especially Dieter, who gave me encouragement to get a graduate level education and who helped me through the difficult times in my life while I was doing my thesis work.

Thanks to the contributors to my graduate work, without which I would not have been able to complete my course work and field work: an Achievement Rewards for college Scientists (ARCS) Scholarship funded by the Lurie Foundation, an Underrepresented Minority Fellowship, a College of Science Society of Archimedes Scholarship, and a Department of Biology Gerdts Memorial Scholarship. 


\section{TABLE OF CONTENTS}

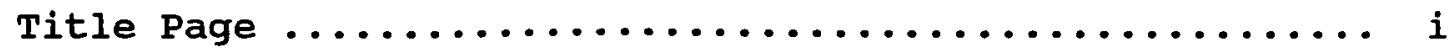

Copyright Page .......................... ii

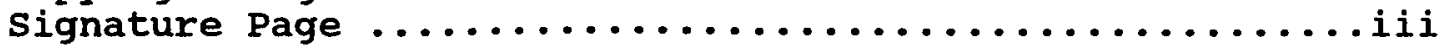

Abstract ................................. iv

Acknowledgements $\ldots \ldots \ldots \ldots \ldots \ldots \ldots \ldots \ldots \ldots \ldots \ldots$. . . . . . . . .

Table of Contents ........................... vi

List of Tables and Figures ..................... vii

Introduction $\ldots \ldots \ldots \ldots \ldots \ldots \ldots \ldots \ldots \ldots \ldots \ldots \ldots \ldots$

Steelhead Life History and Juvenile Habitat

Requirements ...................... 1

otolith Analysis in Age Determination ........... 4

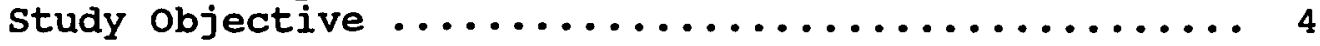

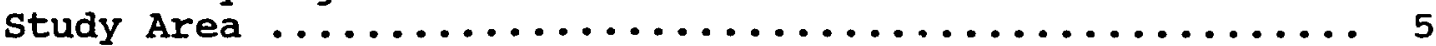

Materials and Methods ...................... 8

Sampling sites $\ldots \ldots \ldots \ldots \ldots \ldots \ldots \ldots \ldots \ldots \ldots \ldots$

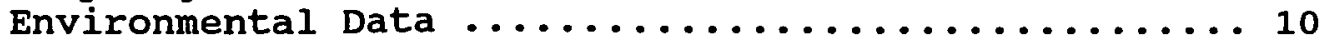

Fish Sampling: Habitat Use, Movements, Size ....... 10

Fish Sampling for Age Determination ............ 12

otolith Analysis ........................ 13

Statistical Analysis ...................... 14

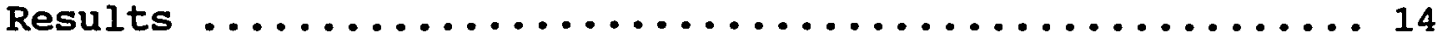

Environmental Data ...................... 14

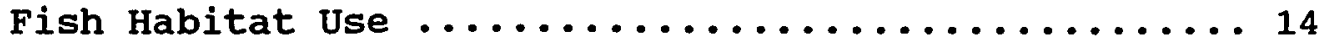

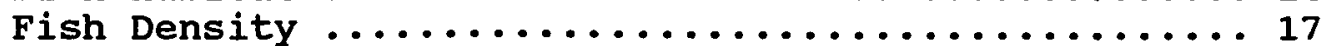

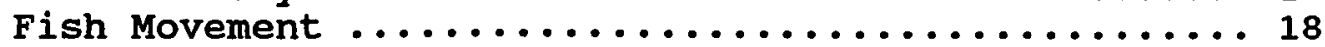

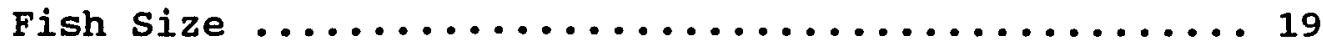

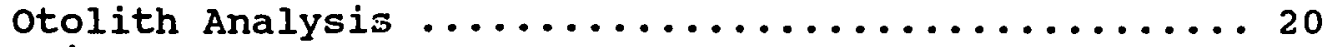

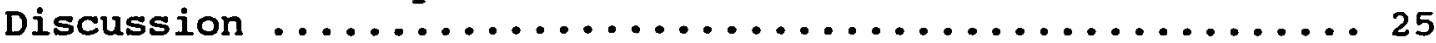

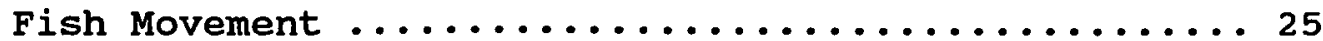

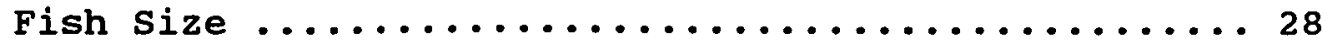

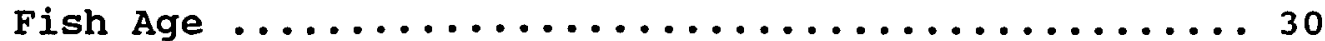

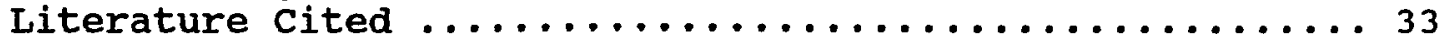




\section{LIST OF TABLES AND FIGURES}

FIGURE 1. Waddell Creek study Area Map, showing sites sampled in July/August and October $1993 \ldots \ldots \ldots \ldots \ldots$

TABLE 1. Summary of sites sampled on Waddell Creek in

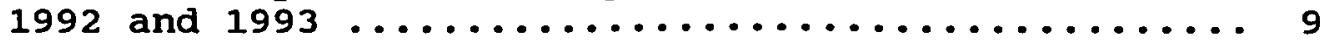

FIGURE 2. Temperatures at a downstream site (\#2) from 03 June to 25 October $1993 \ldots \ldots \ldots \ldots \ldots \ldots \ldots \ldots \ldots$

FIGURE 3. Temperatures at an upstream site (\#7) from 03 June to 25 October $1993 \ldots \ldots \ldots \ldots \ldots \ldots \ldots \ldots . \ldots \ldots$

TABLE 2. Percent of each habitat type sampled and percent steelhead caught by habitat type for July/August and October $1993 \ldots \ldots \ldots \ldots \ldots \ldots \ldots$

TABLE 3. Number of marked and recaptured steelhead by mark type ............................. 19

FIGURE 4. Length frequency distribution of steelhead at upstream versus downstream sites in July and

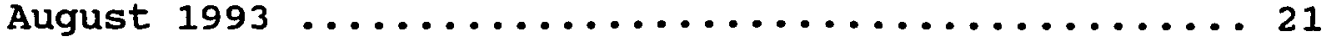

FIGURE 5. Length frequency distribution of steelhead at upstream versus downstream sites in october

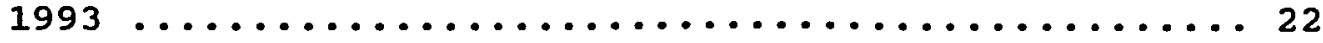

FIGURE 6. Length frequency distribution of steelhead in pool versus run/glide and riffle habitats at downstream sites in october $1993 \ldots \ldots \ldots \ldots \ldots \ldots \ldots . . \ldots 23$

FIGURE 7. Length frequency distribution of steelhead in pool versus run/glide and riffle habitats at upstream sites in october $1993 \ldots \ldots \ldots \ldots \ldots \ldots \ldots . \ldots 24$

FIGURE 8. Age frequency distribution of steelhead at an upstream versus downstream site in october

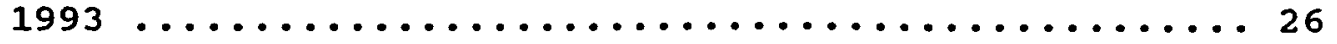

FIGURE 9. Steelhead size versus age at upstream and downstream sites in October 1993.............. 27 


\section{INTRODUCTION}

\section{Steelhead Life History and Juvenile Habitat Requirements}

Steelhead trout (Onchorhynchus mykiss) are an anadromous form of rainbow trout native to the Pacific coast from southern California to Alaska (Shapovalov and Taft 1954, Moyle 1976). Unlike other anadromous pacific salmonids, steelhead often survive spawning, return to the ocean and may spawn multiple times before dying (Shapovalov and Taft 1954, Moyle 1976). Steelhead usually spend one to

three years in fresh water and one to two years in salt water before returning to spawn for the first time (Shapovalov and Taft 1954).

In California the long-term decline of steelhead populations has been attributed to degradation of spawning streams through poor logging techniques, water damming and diverting, and pollution (Moyle 1976, McEwan and Jackson 1993). Seasonal temperature increases, often aggravated by flow reduction, increase fish metabolism and therefore food requirements (Beamish 1964, Facey and Grossman 1990). At the same time, development within watersheds has increased sediment load into streams, often reducing invertebrate production (McEwan and Jackson 1993).

Steelhead size affects dominance relationships (Jenkins 1969, Bovee 1978, Nielsen 1992) and ocean survival (Shapovalov and Taft 1954, Hoar 1976, Smith 1990, McEwan and 
Jackson 1993), therefore, growth rate, and factors that affect it, are important for understanding steelhead ecology. Fish growth rate depends upon factors such as water temperature (which affects basal metabolism), food availability, fish size, and effort involved in getting food. Energy obtained from food consumption must outweigh the costs of swimming and basal metabolism for stream position to be profitable and for growth to occur (Brett 1971, Warren 1971, Smith and Li 1983, Fausch 1984). There is a trade-off between maintaining position in a riffle where food is usually abundant but metabolic cost of swimming is high and maintaining position in a pool where food is usually less abundant but metabolic cost of swimming is low (Jenkins 1969, Jenkins et al. 1970, Smith and Li 1983, Fausch 1984, Facey and Grossman 1990, Nielsen 1992). Heads of pools often offer an optimum mix of high food availability with low swimming cost (Jenkins et al. 1970, Nielsen 1992); dominant fish occupy this preferred habitat (Nielsen 1992).

Juvenile steelhead have been observed to segregate into different microhabitats based on size class (Hartman 1965, Everest and Chapman 1972, Baltz and Moyle 1984, Gatz et al. 1987). This type of dominance hierarchical system is well documented in many salmonid species, with the more aggressive, often larger, fish maintaining the preferred 
foraging habitat (Chapman 1962, Baltz and Moyle 1984, Hearn and Kynard 1986, Taylor 1991, Nielsen 1992) and not moving between habitats throughout the growing season (Mason and Chapman 1965, Jenkins 1969, Nielsen 1992). Yearling steelhead seem to prefer deeper pool habitat year-round (Hartman 1965, Everest and Chapman 1972, Cunjak and Green 1983, Baltz and Moyle 1984) and most young-of-year (YOY) steelhead inhabit and defend riffle habitat during the growing season in spring and summer, and move to deep water pool habitat during the high flow months (Hartman 1965, Everest and Chapman 1972, Cunjak and Green 1982, Baltz and Moyle 1984, Hearn and Kynard 1986). In the absence of abundant yearling steelhead, larger yOY steelhead will maintain position in pools (Hearn and Kynard 1986). The mechanism for dominance and size differences among YoY steelhead is unknown. Two possible hypotheses are: 1) the dominant YOY steelhead could be genetically more aggressive/fit, and thus able to hold the best microhabitats and grow faster; 2) the dominant yoY steelhead could have emerged from the gravels first, and the additional growth period provided a size advantage that ensured possession of the best microhabitats. If the dominant yoY steelhead are more genetically fit, then we would expect that age would not be a contributing factor to the dominance and size. If the dominant YOY steelhead emerged first, then a detailed 
age analysis should indicate that the dominant fish are older and size is related to age.

\section{Otolith Analysis in Age Determination}

In most studies, age classification is based on size alone, rather than more precise measurements, such as using otoliths, which can show daily increments. Many fish species in a variety of environments have been shown to deposit daily rings of calcium carbonate (Campana and Nielson 1985, Geffen 1987, Simoneaux and Warlen 1987, Kline 1993, Morales-Nin et al. 1993). However, non-daily increments have been observed in several instances (Moen and Moksness 1993, Rugolo 1993, Volk et al. 1993) indicating that each situation is different and requires daily increment validation prior to age calculation. Back-calculations are not accurate for estimating size-atage in fish past the larval stage (Bradford and Geen 1987, Chifamba 1993, Volk et al. 1993, Wright 1993); the mechanism controlling increment formation may be unrelated to somatic growth in larger juveniles (Moksness et al. 1993, wright et al. 1993).

study Objective

There were three main objectives of this study. The first objective was to determine if yoY steelhead moved 
between habitats during the growing season. If steelhead maintain position in one habitat, then size may be related to habitat choice. The second objective was to determine if fish in different habitats were of different sizes. If fish were of different sizes in different habitats, then there may be a growth benefit to use of different habitats or a habitat use response to different sizes. The third objective was to determine if fish size was related to age. If larger fish maintaining position in preferred habitat are older, then time of emergence may be related to dominance.

\section{STUDY AREA}

Waddell Creek is located in central California, Santa Cruz County, south of San Francisco and north of Monterey Bay. It empties into the ocean approximately $32 \mathrm{~km}$ northwest of the northern end of Monterey Bay (Figure 1). Because much of Waddell creek is located in Big Basin state Park, it has had limited recent habitat loss and degradation due to human demands on the watershed resources. The steelhead population appears to be doing well despite the fact that they are declining statewide (McEwan 1993, Smith 1994). In addition to steelhead, waddell creek currently contains coho salmon ( 0 . kisutch), threespine stickleback (Gasterosteus aculeatus), prickly sculpin (Cottus asper) and coastrange sculpin (Cottus aleuticus). Its lagoon contains 


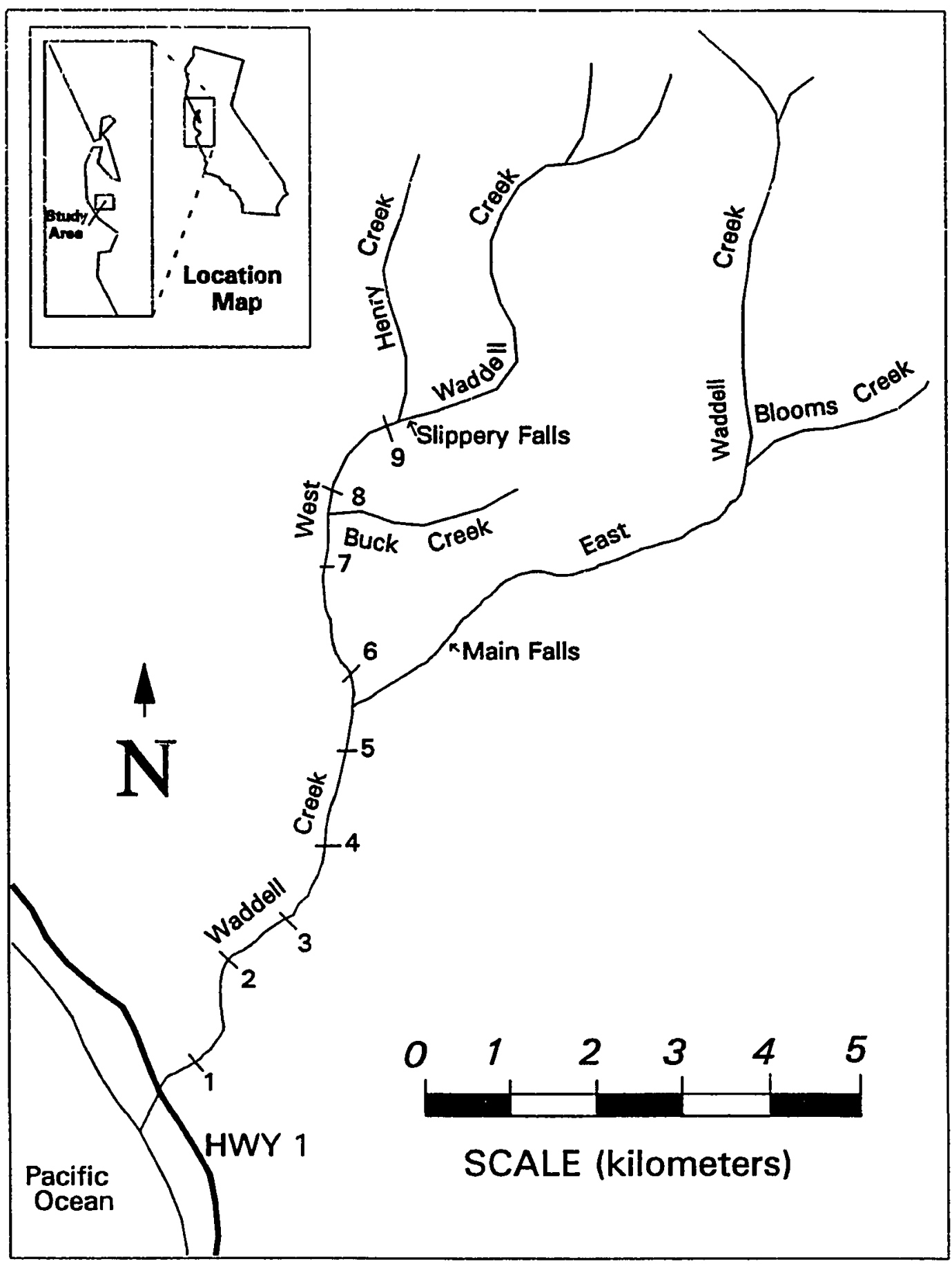

FIGURE 1. Waddell Creek study area map, showing sites sampled in July/August and October 1993. 
estuarine species, including the endangered tidewater goby (Eucyclogobius newberryi) .

Waddell Creek has distinct wet and dry seasons, with more than one-half of the rain falling during December, January, and February (Shapovalov and Taft 1954). During the summer, flows average less than 0.003 cubic meters per second (cms) and upstream are as low as $0.001 \mathrm{cms}$ in fall before the rain starts, but even in drought years no sections go dry.

The stream's two main forks, the East and the West Forks, meet about $5.2 \mathrm{~km}$ upstream of the coast (Figure 1). There is a partial barrier to spawning migration on the west Fork at slippery Falls, $4.3 \mathrm{~km}$ upstream of the confluence. On the East Fork the uppermost limit of spawning migration is at the Main Falls, $1.6 \mathrm{~km}$ upstream of the confluence (Shapovalov and Taft 1954).

Below the falls, the forks consist mostly of pools, stepruns and high gradient riffles over bedrock and boulders (Rosgen 1995, B1 and B2 channel types) which cut through steep-walled canyons, characterized by a forest of Redwood (Sequoia sempervirens), Douglas Fir (Pseudotsuga taxifolia) and Tan Oak (Lithocarpus densiflora). The lower portion of the West Fork (downstream of Buck Creek) and the mainstem below the fork junction is less entrenched with fewer deep pools, and more runs, glides and low gradient riffles (C3 
and $C_{4}$ channel types). The substrate of the West Fork is derived from shale with flat cobbles and frequent pockets of good spawning gravels. Downstream of the forks the substrate is derived from a mixture of shale and sandstone. Sand is abundant and there are few good spawning gravels. The banks of the lower reaches of the forks are lined primarily with Red Alder (Alnum rubra), Big-leaf Maple (Acer macrophyllum), and California Bay (Umbellularia californica), with generally dense shading (Shapovalov and Taft 1954). Below the confluence, the stream is relatively unshaded with a riparian border of alders and willows (Salix spp.)

\section{MATERIALS AND METHODS}

\section{Sampling sites}

To obtain a representative sample of habitat types, five habitats (stations) were chosen per site. Sites were approximately one $\mathrm{km}$ apart. These data were used to determine optimum sample size of habitats and sites for the sampling done between July and October 1993. Thirteen sites were sampled in July and August 1992. In 1993, six sites were sampled in JulY and August, and five of the sites were resampled and three others were sampled in October (Table 1). Sites were resampled at the end of the growing season 
in October 1993 to determine steelhead movements, rearing distribution and late summer growth.

TABLE 1. Summary of sites sampled on Waddell creek 1992 and 1993.

\begin{tabular}{|c|c|c|c|c|}
\hline site & River $\mathbf{k m}$ & $\begin{array}{c}\text { July/August } \\
1992\end{array}$ & $\begin{array}{c}\text { July/August } \\
1993\end{array}$ & $\begin{array}{c}\text { October } \\
1993\end{array}$ \\
\hline$\# 1$ & 1.0 & $\mathrm{x}$ & $\mathrm{x}, *$ & \\
\hline$\# 2$ & 2.3 & $\mathrm{x}$ & $\mathrm{X}, \mathrm{T}$ & $\mathrm{X}, \mathrm{T}$ \\
\hline$\# 3$ & 2.9 & $\mathrm{x}$ & & $\mathrm{x}$ \\
\hline$\# 4$ & 3.5 & $\mathrm{x}$ & & $x$, \\
\hline$\# 5$ & 4.2 & $x$ & $x$ & $x$ \\
\hline$\# 6$ & 5.3 & $\mathrm{X}$ & $\mathrm{X}, \mathrm{T}$ & $\mathrm{X}, *, \mathrm{~T}$ \\
\hline$\# 7$ & 6.3 & $x$ & $\mathrm{x}$ & $\mathrm{x}$ \\
\hline$\# 8$ & 7.6 & $x$ & & $x, \bullet$ \\
\hline$\# 9$ & 8.5 & $\mathrm{x}$ & $\mathrm{x}$ & $\mathrm{x}$ \\
\hline
\end{tabular}

otolith daily rings were validated at two sites. The first was in a relatively unshaded, flat section of stream near the mouth (Site 1) and the second at a shaded section of stream on the West Fork (Site 6). Two sites were chosen for fish removal and subsequent otolith analysis. One was on the less shaded mainstem (Site 4) and the second was upstream on the shaded West Fork (Site 8). Each site had an area with a continuous run, riffle and pool sequence, and neither of the sites had been sampled previously so that the 
fish had no prior stresses.

\section{Environmental Data}

Habitat type was assigned using the following criteria (Bisson et al. 1982): Pools = any habitat with visible scour; Glides = flatwater with even substrate; Runs = flatwater with uneven substrate; and riffles = shallow habitat with uneven substrate and surface turbulence. For the purpose of this study, runs and glides were grouped together, because these two habitats were often continuous and difficult to separate. In order to determine amount of habitat, length and width were measured to the nearest 0.2 meter with a measuring tape and mean depth and range of depth (from the shallowest 10 percent to the deepest 10 percent) were estimated to the nearest 0.03 meter using a marked rod.

Temperature regimes in the relatively unshaded mainstem (Site 2) and in the shaded West Fork (Site 7) were determined with maximum minimum thermometers. Temperatures were recorded three to four times a month from 03 June to 25 October 1993.

Fish Sampling: Size, Movements and Habitat Use

Fish were sampled in each station, or individual pool, run or riffle habitat, by electrofishing (Smith Root Type 
VII) using two or three passes. To prevent fish movement between stations, block nets were set enclosing the habitat prior to sampling each habitat station. Fish were measured in $5 \mathrm{~mm}$ increments standard length (SL) and separated into YOY and age $1+$ fish based upon length frequency at each site. Size and age analysis in this study dealt only with YOY fish.

Five randomly selected fish per station were anesthetized with tricaine methanesulfonate (MS-222, Argent Chemical Laboratories) prior to fin-marking all six sites sampled in July and August 1993. Fish were given a unique mark by injecting fins with acrylic cadmium-based paint, alacian blue dye or phenol red dye using either a dental injector or a syringe with a $261 / 2$ gauge needle. Dental injection appeared to be less stressful on the fish as less handling time was required and recovery was faster then with needle injected fish. However, later sampling indicated that the needle injection gave a more permanent mark. A different color and/or a different fin was marked at each habitat allowing for easy identification of individual fish at later sampling dates and for detection of movement among stations between sampling dates. To further detect movement among habitat stations, habitats directly downstream and upstream of the site were sampled when marked fish were found during resampling. 
Fish Sampling for Age Determination

Daily ring deposition was confirmed twice during the growing season, in late June at the downstream most site (\#1) and in late september at an upstream site (\#6). Ten YOY steelhead, captured by electroshocking, were placed in a bucket of aerated stream water in a cooler of ice. For two hours the temperature of the water in the bucket was maintained at least 12 degrees $c$ lower than the current stream temperatures. This process has been shown to slow down the deposition of calcium and therefore mark the otoliths with a dark ring without harming the fish (Bergstedt et al. 1990, Volk et al. 1990, Titus and Mosegaard 1993, and Volk et al. 1994). Then, the fish were placed in a $0.6 \mathrm{~cm}$ wire mesh enclosure which allowed water and insects to flow through. Nine days later the fish were sacrificed and the otoliths were analyzed for the appearance of nine rings since the marking.

Fish taken for otolith analysis were collected by electrofishing, in october, at two sites not previously sampled in 1993. Because chemicals deteriorate otolith bones, distorting increment counts, fish were sacrificed by freezing (Secor et al. 1992). 
otolith Analysis

The largest of the three otolith bones, the sagitta, was removed from all sacrificed fish by making a horizontal cut from just above the eye to the first gill arch and probing in the semi-circular canal with tweezers. Once the sagitta was extracted, it was carefully cleaned with water and mounted in a two stage resin. Araldite CY $8702 /$ Hardener HY 8700 (Ted Pella, Inc.) was used instead of Spurr (Electron Microscopy Sciences) because it is not carcinogenic, it can harden at various temperatures without becoming brittle, and it hardens faster than spurr. After hardening, the resin cubes were placed in a specially made metal frame and ground on one side with a series of fine sand papers and polishing cloths. Repeated examination under light microscope was required while sanding so that the center of the otolith could be found (secor et al. 1992). Once the center was located, the cube containing the center sagittal section of otolith, was mounted with the ground side down on a glass microscope slide and the other side of the resin cube was ground and finally etched for a couple of seconds with $5-7 \%$ ethylenediamine tetraacetcetic acid (EDTA, Fisher scientific) to accentuate the rings. The daily rings were counted using a light microscope at 4001000 power, focusing up and down for best resolution (Secor et al. 1992). 
statistical Analysis

Fish size data were analyzed using a parametric multivariate analysis of variance (ANOVA) for unequal sample size to test whether there was a size difference between upstream and downstream sites and among different habitat types within sites. Age data were analyzed using an ANOVA to test whether there was an age difference of $\mathrm{fish}$ in different habitat types and between upstream and downstream sites. Correlation analysis was done between size and age at both upstream and downstream sites.

\section{RESULT8}

\section{Environmental Data}

Temperatures were generally similar at the two sampling sites. At site 2, downstream on Waddell creek, temperatures ranged from 12.2 to 20.6 degrees C (Figure 2). At site 6, upstream on West Fork Waddell, temperatures ranged from 11.1 to 20.0 degrees $C$ (Figure 3 ). However, the maximum temperatures at the downstream site were generally higher than at the upstream site in June and July (Figures 2 and 3), when fish were still actively growing. 


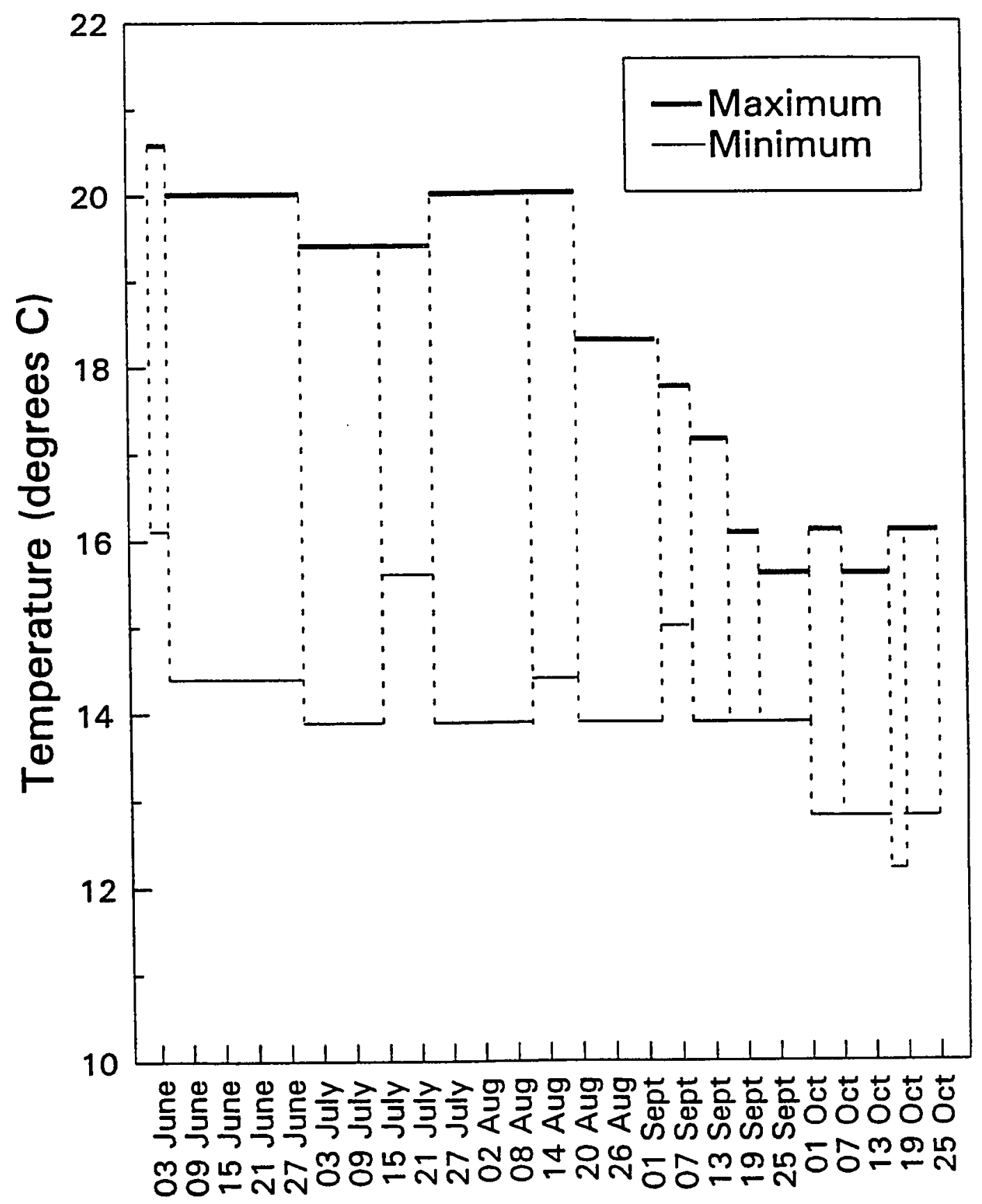

Dates

FIGURE 2. Temperatures at a downstream site (\#2) from 03 June to 25 October 1993. 


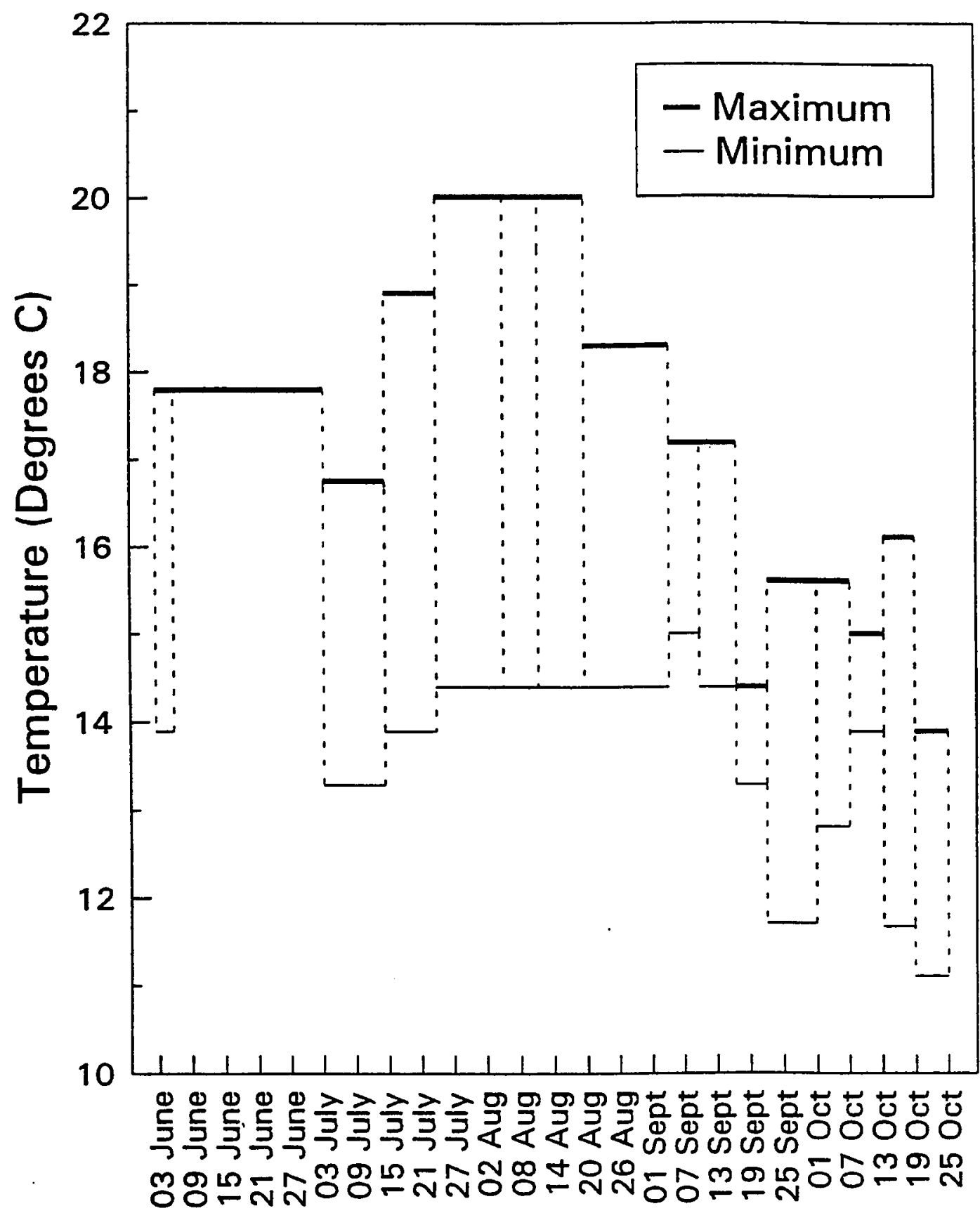

\section{Dates}

FIGURE 3. Temperatures at an upstream site (\#6) from 03 June to 25 October 1993. 


\section{Fish Habitat Use}

Run/glide habitats were sampled most heavily during both the July/August 1993 and the October 1993 sampling periods, followed by pool and riffle habitats (Table 2). However, YOY steelhead were most abundant in pools with overall relative abundance substantially greater than sampled habitat in both sampling periods. Riffles contained approximately the same percentage of YOY steelhead as the percent habitat sampled, while run/glide habitat contained substantially less fish than habitat sampled (Table 2). It is interesting to note that although $1+$ steelhead were not the subject of this research, they were found predominantly in pool habitats (Table 2).

TABLE 2. Percent of each habitat type sampled and percent steelhead caught by habitat type for July/August and October 1993.

\begin{tabular}{|c|c|c|c|c|c|}
\hline \multirow[b]{2}{*}{ July/August } & & & Pool & Run/Glide & Riffle \\
\hline & & & & & \\
\hline \multirow{7}{*}{ October } & $\%$ & Habitat & $34 \%$ & $44 \%$ & $22 \%$ \\
\hline & $\%$ & YOY & $42 \%$ & $33 \%$ & $25 \%$ \\
\hline & $\%$ & $1+$ & $77 \%$ & $23 \%$ & $0 \%$ \\
\hline & & & & & \\
\hline & $\%$ & Habitat & $36 \%$ & $38 \%$ & $26 \%$ \\
\hline & $\frac{8}{8}$ & YOY & $51 \%$ & $23 \%$ & $26 \%$ \\
\hline & $\%$ & $1+$ & $81 \%$ & $18 \%$ & $1 \%$ \\
\hline
\end{tabular}


Fish Density

At the five sites which were sampled in July/August 1993 and then resampled in october 1993, steelhead densities generally declined during the summer months. I captured 685 YOY steelhead in July and August, compared to 538 YOY in October (78.5\%). Yearling densities only declined by $4.2 \%$ (from 71 in July and August to 68 in October).

\section{Fish Movement}

Fish marking and subsequent resampling indicated that steelhead did not move between habitats during the summer months. Forty-five steelhead were marked with dye (either alacian blue or phenol red), but no dye-marked fish were recaptured. However, of the 105 steelhead marked with cadmium-based paint, 46 (43.8\%) were recaptured at the same habitat station at which they were marked. No marked steelhead were found in different habitats.

Red cadmium-based paint appeared to have the best relative retention rate (61\% of fish were recovered) when compared to orange (4\%) and yellow (44\%). Red paint also retained its original color, while orange and yellow turned brown and were difficult to distinguish from each other. Paint injected by syringe was retained better $(51 \%$ of $\mathrm{fish}$ were recovered) than paint injected by the dental injector $(32 \%)$ (Table 3) 
TABLE 3. Number of marked and recaptured steelhead by mark type.

\begin{tabular}{rccccc}
\hline Mark Type & Equipment & Fin & \# Marked & \# Recaps & \& Recaps \\
\hline red paint & syringe & caudal & 12 & 10 & 83.38 \\
red paint & syringe & dorsal & 9 & 6 & 66.78 \\
red paint & injector & caudal & 10 & 6 & 608 \\
red paint & injector & dorsal & 5 & 0 & 08 \\
red paint & injector & anal & 5 & 3 & 608 \\
orange paint & syringe & caudal & 6 & 0 & 08 \\
orange paint & injector & caudal & 10 & 1 & 108 \\
orange paint & injector & dorsal & 5 & 0 & 08 \\
orange paint & injector & anal & 5 & 0 & 08 \\
yellow paint & syringe & caudal & 3 & 0 & 08 \\
yellow paint & syringe & dorsal & 5 & 2 & 408 \\
yellow paint & injector & caudal & 10 & 6 & 608 \\
dye & injector & all & 45 & 0 & 08 \\
\hline
\end{tabular}

Fish size

Mean size at both upstream and downstream sites increased only slightly from July/August to October 1993. Mean size at downstream sites was $59 \mathrm{~mm}$ in July/August and increased only $7 \mathrm{~mm}$ to $66 \mathrm{~mm}$ in October. Mean size at upstream sites was $51 \mathrm{~mm}$ in July/August and increased only 3 $\mathrm{mm}$ to $54 \mathrm{~mm}$ in October (Figures 4 and 5).

Analysis of variance of standard lengths of YOY steelhead between upstream or downstream sites, regardless of habitat type, indicated that upstream steelhead were significantly smaller than downstream steelhead in July/August $1993(F=54.60, d f=1, P>0.0001)$ (Figure 4) and 
October $1993(F=127.70, d f=1, P>0.0001)$ (Figure 5).

In July/August, analysis of variance indicated no significant length difference of steelhead among different habitats at upstream sites $(\mathrm{F}=1.62, \mathrm{df}=2, \mathrm{P}>0.2000)$ and at downstream sites $(\mathrm{F}=1.03, \mathrm{df}=2, \mathrm{P}>0.3561)$. In October, length differences between steelhead in different habitats at downstream sites were nearly significant ( $F=2.46, d f=2$, P>0.0868), with riffle fish being smaller (Figure 6). steelhead lengths in different habitats at upstream sites were significantly different $(F=5.78, d f=2, P>0.0034)$ (Figure 7). Steelhead in pool habitat were larger than those in either run/glide or riffle habitats.

\section{otolith Analysis}

All fish cold stressed and held for an additional 9 days showed a clear otolith stress mark, followed by 9 increments. Waddell creek steelhead produced daily otolith increments in summer and fall.

Analysis of variance of age of steelhead showed no significant age difference of steelhead in different habitats in October 1993, at the upstream site ( $F=.94, d f=2$, P>0.3328). However, age differences at the downstream site were nearly significant $(F=2.53, \mathrm{df}=2, \mathrm{P}>0.1122)$, with pool fish being older. There was a significant age difference 


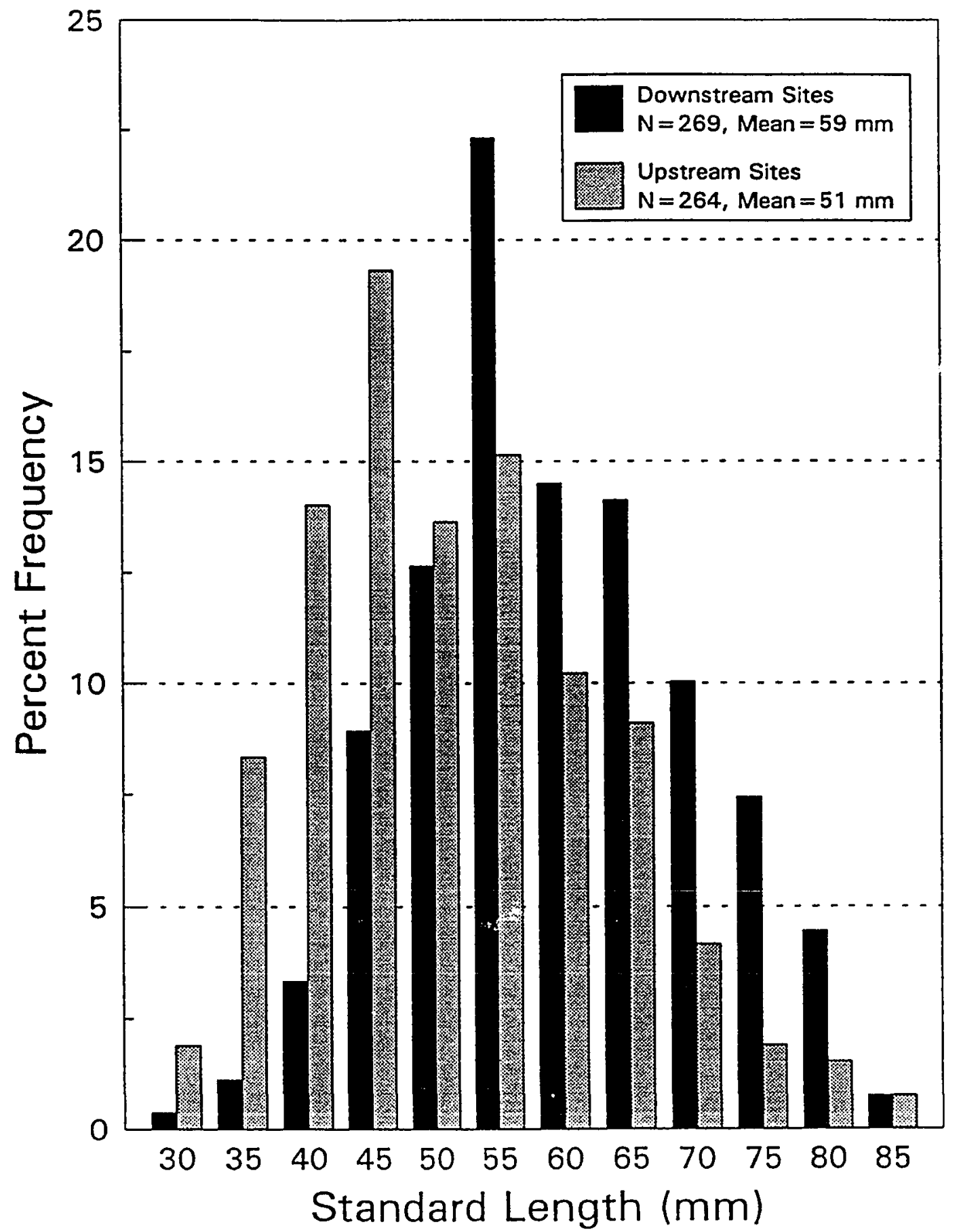

FIGURE 4. Length frequency distribution of steelhead at upstream versus downstream sites in July and August 1993. 


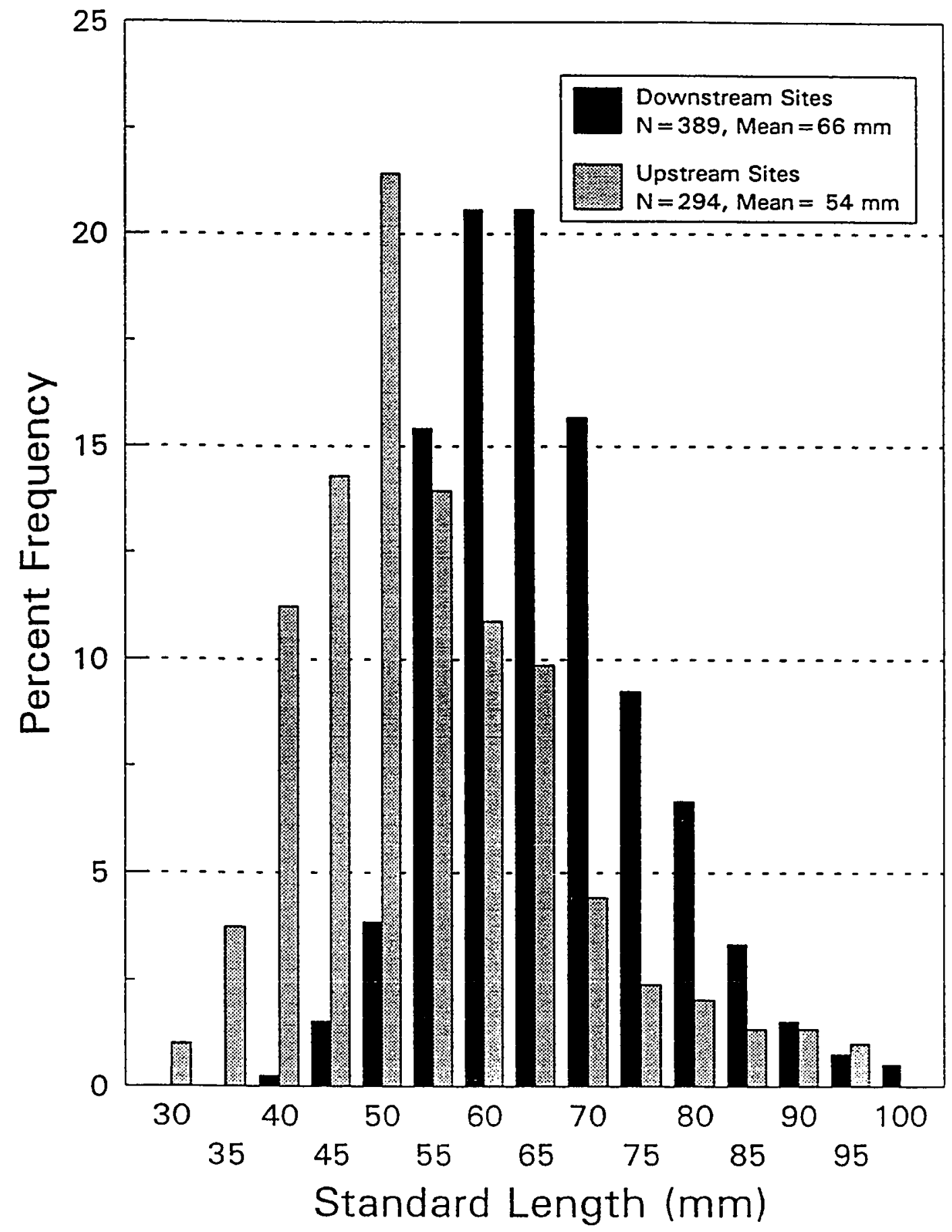

FIGURE 5. Length frequency distribution of steelhead at upstream versus downstream sites in october 1993. 


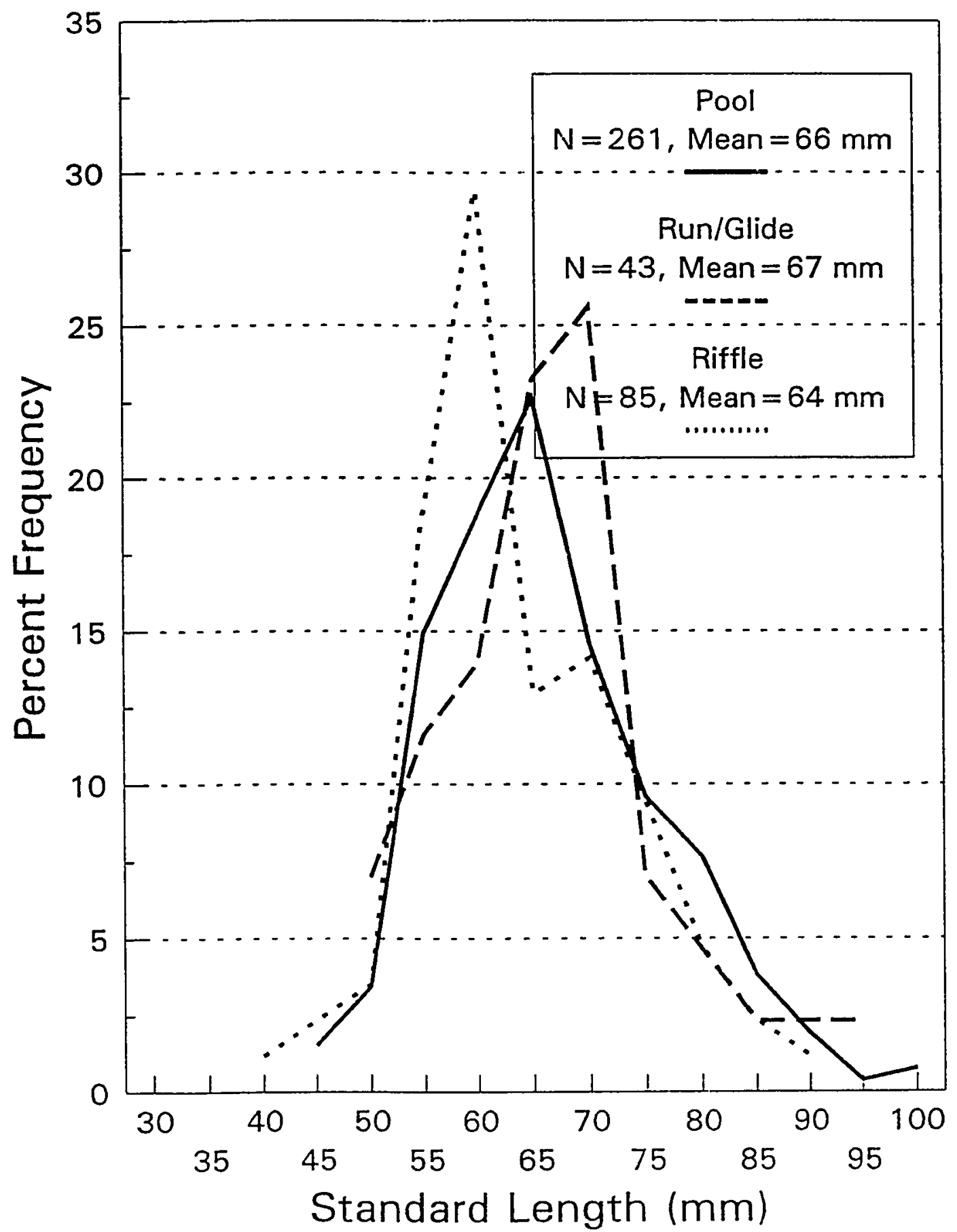

FIGURE 6. Length frequency distribution of steelhead in pools versus run/glide and riffle habitat at downstream sites in October 1993. 


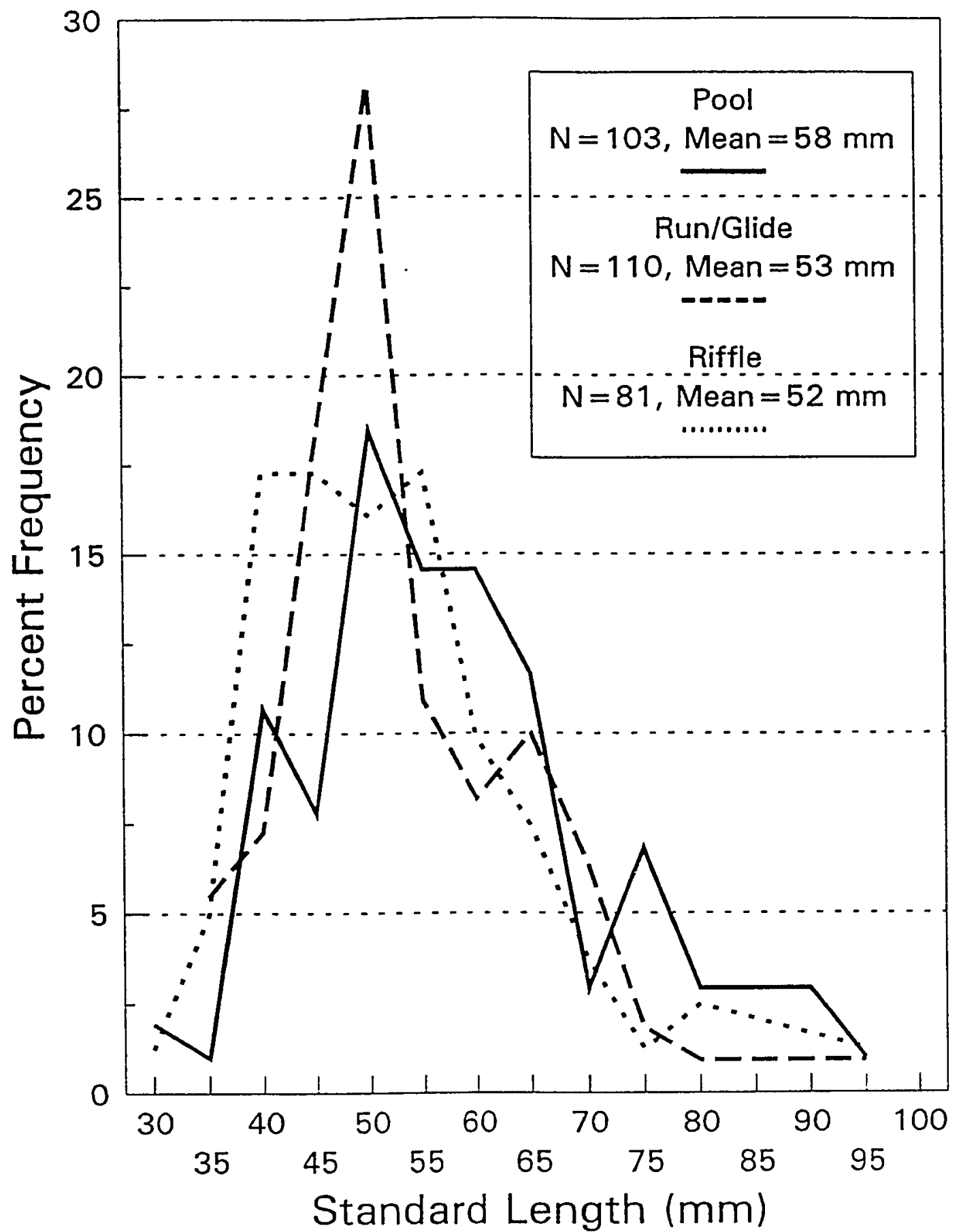

FIGURE 7. Length frequency distribution of steelhead in pools versus run/glide and riffle habitat at downstream sites in October 1993. 
between upstream and downstream steelhead regardless of rearing habitat $(\mathrm{F}=29.44, \mathrm{df}=1, \mathrm{P}>0.0001)$, with downstream fish being older (Figure 8 ).

steelhead size and age were strongly correlated at the upstream site $(r=0.724, P<0.001)$, the downstream site $(r=0.746, P<0.001)$, and at both sites combined $(r=0.730$, P<0.001) (Figure 9). Since steelhead emerge from the gravels at about 20 to $25 \mathrm{~mm}$ SL this correlation also shows that there is an $\mathrm{X}$-axis intercept at approximately 120 days.

\section{DIsCussion}

\section{Fish Movement}

Results indicated that steelhead maintained position in a single habitat during the growing season, confirming past findings (Chapman 1962, Mason and Chapman 1965, Jenkins 1969, Baltz and Moyle 1984). No marked fish were recaptured outside of their original habitat either in resampled habitat or in habitats upstream and downstream of each site. slightly less than half of the steelhead marked with cadmium-based paint were recaptured, but densities were down at all sites during the October 1993 sampling when compared to the July/August sampling. The low recapture rate could be due to natural density dependent mortality over the summer, to handling mortality and/or to loss of marks. 


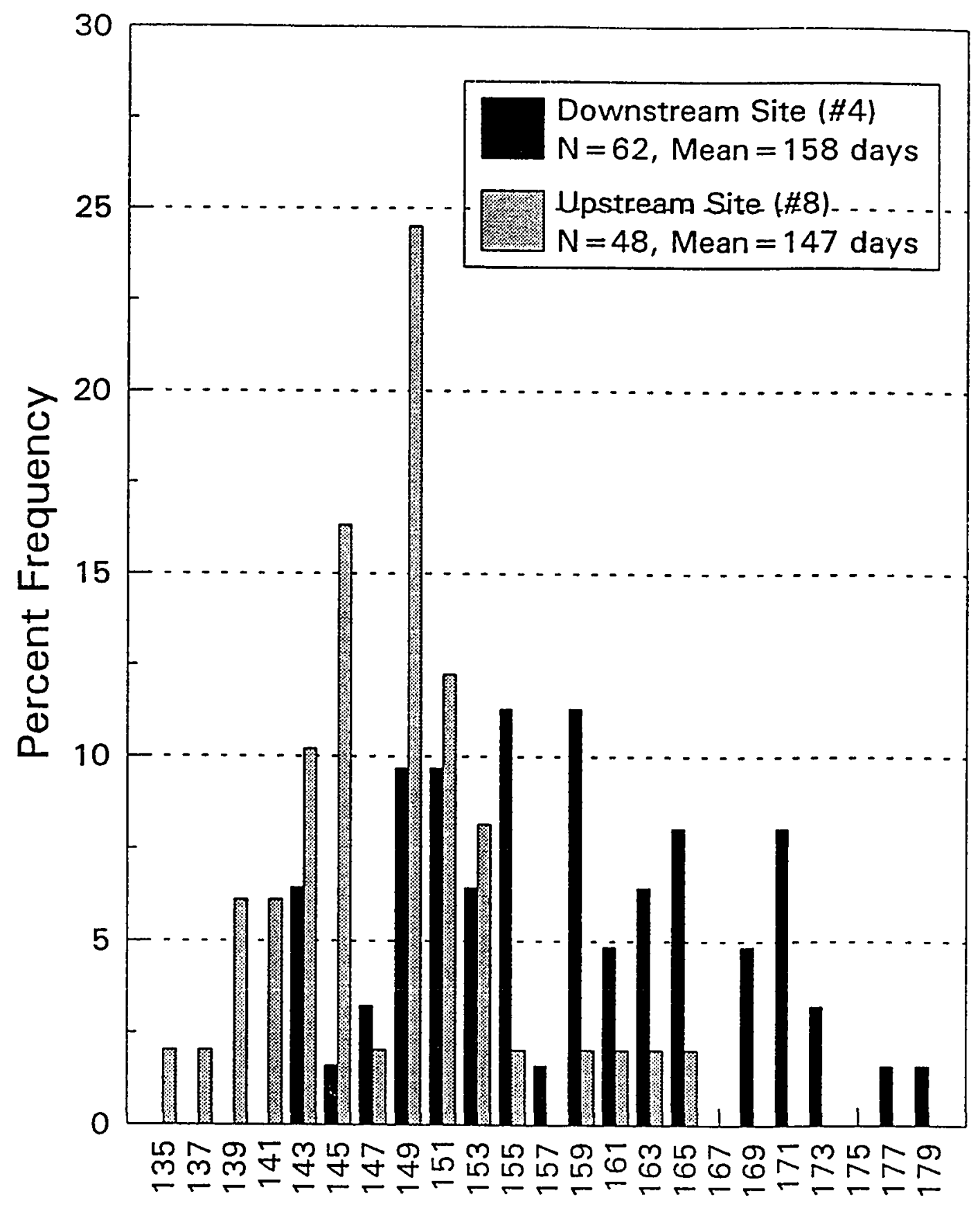

\section{Age (days)}

FIGURE 8. Age frequency distribution of steelhead at upstream versus a downstream site in october 1993. 


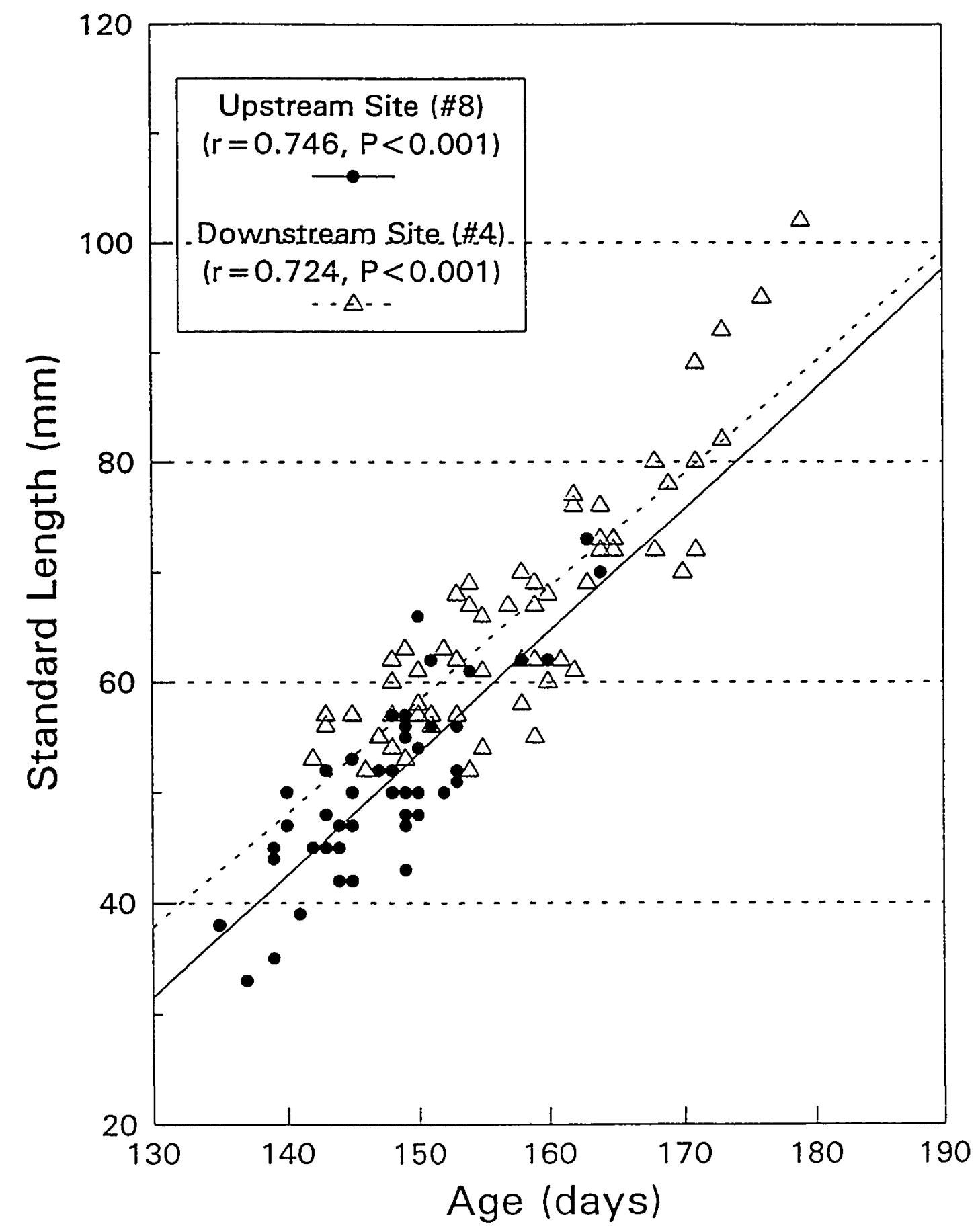

FIGURE 9. Steelhead size versus age at upstream and downstream sites in October 1993. 


\section{Fish size}

Size of steelhead captured in July/August 1993 did not differ significantly among habitats, failing to agree with other studies (Hearn and Kynard 1986) which show that larger YOY steelhead maintain position in pool habitat and smaller YOY steelhead maintain position in riffle or run habitat. However, size analysis of steelhead captured in October 1993 did confirm past findings. This discrepancy could due to several factors:

1) Sampling in the summer occurred over a 42 day period, from July 1 to August 11 at a time when steelhead were still actively growing. Separating out July from August and repeating the analysis was not possible due to sample size constraints. October sampling took place over a shorter, 25 day period, from October 1 to October 25; stream flows were at their lowest and fish growth was probably limited. Future sampling should be done over as short a period as possible, so that the length of the sampling period is not a factor in the analysis.

2) Fish lengths were recorded in $5 \mathrm{~mm}$ increments. This method may not have been precise enough to allow differences to be seen, especially when the fish were smaller and the range between sizes was smaller, as it was during the July/August sampling. Future length data should be recorded to the nearest $1 \mathrm{~mm}$, the most precise measurement possible 
in the field.

3) Steelhead could have been more similar in size early in the growing season and, because of rearing habitat conditions, could have grown disproportionately in late summer in different habitat types. This possibility suggests that larger steelhead, maintaining position in pools, are not dominant because they are larger, but they are larger because they are dominant and maintaining position in preferred rearing habitat.

Size analysis also showed a difference between upstream and downstream steelhead regardless of sampling time or rearing habitat. Downstream steelhead were significantly larger than upstream steelhead. This difference could be from temperature, food availability, light and age/or differences. Maximum-minimum temperatures were slightly different between upstream and downstream sites on Waddell creek. In retrospect, however, the upstream thermometer should have been placed at a site further upstream, not just upstream of the junction of East Fork Waddell. Ambient temperature readings indicated that temperatures generally decreased upstream on the West Fork.

There was good substrate for insect production at the lower two sites on West Fork Waddell (Sites 6 and 7), but not further upstream. The bedrock and boulder substrate found upstream on West Fork Waddell probably produces less 
invertebrate food than the gravely substrate found downstream. With less food available the upstream steelhead would grow more slowly than the downstream steelhead.

The canopy at the upstream sites was more dense than at downstream sites. Upstream there are redwoods and douglas fir, which allow less light to reach the creek than do alders and willows found downstream. The evergreen canopy upstream also may have greater impact on algae growth early in the season. Less light not only leads to less algae and insect production, but also makes it more difficult for the fish to see to feed.

Finally, age could be a major factor contributing to the size difference between upstream and downstream fish. Downstream steelhead were older than upstream steelhead.

\section{Fish Age}

Despite the small sample size of fish taken for otolith analysis, otolith age determination indicated that downstream steelhead emerged from the gravels earlier than the upstream steelhead, and that there was a strong relationship between fish size and age. Age accounted for more than half of the variation in fish size $\left(r^{2}=0.532\right)$, indicating that habitat use, invertebrate availability, temperature, light and stream flow were all less important than age in determining fish size. These results suggest 
that there should be a strong genetic benefit to spawning early, however, there have still been many late spawners in Waddell creek (Smith 1994). This could be explained by late spring storms, which periodically wash out redds of early spawners; in some years only offspring of late spawning fish may survive. Genetic studies comparing early and late spawning steelhead may shed some light on this phenomenon. The correlation analysis also showed that these steelhead did not grow very much for 120 days of their life. The small mean fish size differences between the July/August and October sampling indicated that these fish did not grow much past July, when stream flows were low and drifting invertebrates were probably scarce (Smith and $\mathrm{Li}$ 1983). If a fish emerged in May it may have had sixty days of good conditions for growth, but if it emerged in June it may only have had thirty days of good growth. During the summer months fish were maintaining size, rather than growing. Therefore, the fish that emerged earlier in the year were larger and more likely to make it through the winter months and eventually to smolt and go to the ocean (Shapovalov and Taft 1954, Smith 1990, McEwan and Jackson 1993).

Age differences between upstream and downstream fish may have been caused by different spawning times (earlier spawning downstream) or, more probably, by temperature differences during incubation (Leitritz and Lewis 1980), 
with possibly cooler water and slower development upstream. Temperatures could be recorded during the spawning and incubation seasons to determine if temperatures differ from upstream to downstream.

Age analysis of steelhead between different habitat types indicated that there was no significant age difference. However, there were small sample sizes of fish for individual habitats, and the analysis at downstream sites was still nearly significant. July/August fish sizes also did not differ among habitats, therefore this study did not show that larger or older steelhead showed a clear pattern of habitat distribution. There is a need to observe marked fish, especially early in summer, to see if age or size are related to dominance between and within habitats. The lack of movement between habitats found in this study from July to October indicates that aggressive behavior in late summer is not a factor in habitat distribution. Habitat distribution may just be random and the "lucky" fish get the preferred pool habitat and thus grow to be larger by the end of the growing season.

Comparison with different species of salmonids also might be done. Coho, which emerge earlier, have been observed to be dominant over steelhead (Nielsen 1992), and it would be interesting to see if age plays a role in this dominance hierarchy • 


\section{LITERATURE CITED}

Baltz, D. M., and P. B. Moyle. 1984. Segregation by species and size classes of rainbow trout, salmo gairdneri, and Sacramento sucker, catostomus occidentalis, in three California streams. Envir. Bio. Fish. 10:101-110.

Beamish, F. W. H. 1964. Respiration of fishes with emphasis on standard oxygen consumption. Can. J. Zool. 42:177-187.

Bergstedt, R. A., R. L. Eshenroder, C. Bowen, J. G. Seelye, and J. C. Locke. 1990. Mass-marking of otoliths of lake trout sac fry by temperature manipulation. Amer. Fish. Soc. Sym. 7:216-223.

Bisson, P. A., J. L. Nielsen, R. A. Palmson, and L. E. Grove. 1982. A system of naming habitat types in small streams, with examples of habitat utilization by salmonids during low stream flow. Symposium on Acquisition and Utilization of Aquatic Habitat Inventory Information. Western Division, American Fisheries Society. Bethesda, Maryland, USA.

Bovee, K. D. 1978. Probability-of-use criteria for the family Salmonidae. Instream Flow Information Paper 4, U.S. Fish Wild. Serv., FWS/OBS-78/07. 79pp.

Bradford, M. J., and G. H. Geen. 1987. Size and growth of juvenile chinook salmon back-calculated from otolith growth increments. Pages 453-461 In: R. C. Summerfelt and G. E. Hall (eds.), Age and Growth of Fish. Iowa State University Press, Ames.

Brett, J. R. 1971. The metabolic demand for oxygen in fish, particularly salmonids, and a comparison with other vertebrates. Respir. Physiol. 14:151-170.

Campana, S. E., and J. D. Nielson. 1985. Microstructure of fish otoliths. Can. J. Fish. Aquat. Sci. 42:1014-1032.

Chapman, D. W. 1962. Aggressive behavior in juvenile coho salmon as a cause of emigration. J. Fish. Res. Bd. Can. 9:1047-1080. 
Chifamba, P. C. 1993. Comparison between fish length and otolith growth; an investigation in the potential use of individual fish in the study of growth pattern in kapenta, Limnathriss miodon. Lake Kariba Fisheries Research Institute, Box 75, Kariba, Zimbabwe. Unpublished. Presented at the Fish otolith Research and Application Symposium, South Carolina, January 1993 .

Cunjak, R. A., and J. M. Green. 1982. Habitat utilization by brook char (Salvelinus fontinalis) and rainbow trout (Salmo gairdneri) in Newfoundland streams. Can. J. Zool. 61:1214-1219.

Everest, F. H. and D. W. Chapman. 1972. Habitat selection and spatial interaction by juvenile chinook salmon and steelhead trout in two Idaho streams. J. Fish. Res. Bd. Can. 29:91-100.

Facey, D. E., and G. D. Grossman. 1990. The metabolic cost of maintaining position for four North American Fishes: effects of season and velocity. Phys. Zool. 63:757776 .

Fausch, K. D. 1984. Profitable stream positions for salmonids: relating specific growth rate to net energy gain. Can. J. Zool. 62:441-451.

Gatz, A. J. Jr., M. J. Sale, and J. M. Loar. 1987. Habitat shifts in rainbow trout: competitive influences of brown trout. Oecologia 74:7-19.

Geffen, A. J. 1987. Methods of validating daily increment deposition in otoliths of larval fish. Pages 223-240 in R. C. Summerfelt and G. E. Hall eds. Age and Growth of Fish. Iowa State University Press, Ames.

Hartman, G. F. 1965. The role of behavior in the ecology and interaction of underyearling coho salmon (Oncorhynchus kisutch) and steelhead trout (Salmo gairdneri) . J. Fish. Res. Bd. Can. 22:1035-1081.

Hearn, W. E. and B. E. Kynard. 1986. Habitat utilization and behavioral interaction of juvenile Atlantic salmon (Salmo salar) and rainbow trout ( $S$. gairdneri) in tributaries of the White River of Vermont. Can. $J$. Fish. Aquat. Sci. 43:1988-1998. 
Hoar, W. S. 1976. Smolt transformation: evolution, behavior, and physiology. J. Fish. Res. Bd. Can. $33: 1234-1252$.

Jenkins, T. M. Jr. 1969. Social structure, position choice and spacial distribution of two trout species (Salmo trutta and $s$. gairdneri) resident in mountain streams. Anim. Behav. Monogr. 2:57-123.

Jenkins, T. M. Jr., C. R. Feldmeth and G. V. Elliot. 1970. Feeding of rainbow trout (Salmo gairdneri) in relation to abundance of drifting invertebrates in a mountain stream. J. Fish. Res. Bd. Can. 27:2356-2361.

Kline, L. L. 1993. Factors influencing the production of daily growth increments in otoliths of young-of-theyear striped bass, Marone saxatilis. Maryland Dept. of Natural Resources, Fisheries Research Program, 580 Taylor Ave. Annapolis, MD 21111401. Unpublished. Presented at the Fish otolith Research and Application Symposium, South Carolina, January 1993.

Leitritz, E. and R. C. Lewis. 1980. Trout and salmon culture (hatchery methods). Calif. Fish. Bull. no. 164. Univ. of Calif.

McEwan, D., and T. A. Jackson. 1993. Steelhead Management Plan for California. California Department of Fish and Game, Inland Fisheries Division, $1416 \mathrm{Ninth} \mathrm{St.} \mathrm{Rm.}$ 1251, Sacramento CA 95814. 167pp.

Mason, J. C., and D. W. Chapman. 1965. Significance of early emergence, environmental rearing capacity, and behavioral ecology of juvenile salmon in stream channels. J. Fish. Res. Bd. Can. 22:173-190.

Moen, V. and E. Moksness. 1993. Effects of light regimes and somatic growth rate on the daily increment formation in otoliths of Salveinus alpinus. University of Trondheim, Zoological institute, Brattora Research Station, Aquaculture Division, N-7055 Dragvoll, Norway. Unpublished. Presented at the Fish otolith Research and Application Symposium, South Carolina, January 1993 . 
Moksnes, E., K. Rukan, L. Ystanes, A. Folkvork, and A. Johannessen. 1993. Comparison of somatic and otolith growth in north sea herring (Clupea harengus $I_{.}$) larvae; evaluation of growth dynamic in mesocosms. Institute of Marine Research, $\mathrm{N}-4817 \mathrm{His}$, Norway . Unpublished. Presented at the Fish otolith Research and Application Symposium, South Carolina, January 1993 .

Morales-Nin, B., S. Massuti, E. Guitierrez. 1993. Daily growth rings in the otoliths of sparus aurata reared in different conditions. Institut d'Estudies Avancats de les illes Balears, Campus Universitario, 07071 Palma de Mallorca, Spain. Unpublished. Presented at the Fish otolith Research and Application Symposium, South Carolina, January, 1993.

Moyle, P. B. 1976. Inland fishes of California. pp. 131132. University of California Press. Berkeley, CA. $405 \mathrm{p}$.

Nielsen, J. L. 1992. Microhabitat-specific foraging behavior, diet, and growth of juvenile coho salmon. Trans. Amer. Fish. Soc. 121:617-634.

Rosgen, D. L. 1995. A classification of natural rivers. In press 1995 by Catena, Elsiever Publications, Amsterdam.

Rugolo, L. J., L. L. Kline, and K. S. Knotts. 1993. Validation of daily otolith increments in juvenile striped bass (Marone saxatilis). Maryland Department of Natural Resources, Fisheries Research Program, Tawes State Office Building, 580 Taylor Avenue, B-2, Annapolis, MD 21401. Unpublished. Presented at an otolith Symposium, North Carolina, January 1993.

Secor, D. H., J. M. Dean, and E. H. Laban. 1992. Otolith removal and preparation for microstructural examination. Chapter 3, pp. 19-57 In: Stephenson, D. and S. Campana (eds.), otolith microstructure examination and analysis. Special Publ. Can. J. Fish. Aquat. Sci. 117.

Shapovalov, L. and A. C. Taft. 1954. The life histories of the steelhead (Salmo gairdneri gairdneri) and silver salmon (Oncorhynchus kisutch) with special reference to Waddell Creek, California, and recommendations regarding their management. Calif. Fish and Game Fish Bulletin 98. 303 pp. + apps. 
Simoneaux, L. F. and S. M. Warlen. 1987. Occurrence of daily growth increments in otoliths of juvenile Atlantic menhaden. Pages 443-452 In: R. C. Summerfelt and G. E. Hall (eds.), Age and Growth of Fish. Iowa State University Press, Ames.

Smith, J. J. 1990. The effects of sand bar formation and inflows on aquatic habitat and fish utilization in Pescadero, San Gregorio, Waddell and Pomponio Creek estuary/lagoon systems, 1985-1990. Report prepared under interagency agreement 84-04-324, between Trustees for California state University and the California Department of Parks and Recreation.

Smith, J. J. 1994. Status of steelhead in Central California. Unpublished. San Jose State University, Department of Biological Sciences, San Jose, CA 95192.

Smith, J. J and H. W. Li. 1982. Energetic factors influencing foraging tactic of juvenile steelhead trout, Salmo Gairdneri. Pages 173-180 In: D. L. G. Noakes, B. G. Lindquist, G. S. Helfman, and J. A. Ward (eds.), Predators and Prey in Fishes. Junk, The Hague.

Taylor, E. B. 1991. Behavioural interaction and habitat use in juvenile chinook, oncorhynchus tshawytscha, and coho, o. kisutch, salmon. Anim. Behav. 42:729-744.

Titus, R. G. and H. Mosegaard. 1992. Fluctuating recruitment and variable live history of migratory brown trout salmo trutta in a small unstable stream. J. Fish Bio. 41:239-255.

Volk, E. C., S. L. Schroder, and K. L. Fresh. 1990. Inducement of unique otolith banding patterns as a practical means to mass-marking juvenile pacific salmon. Amer. Fish. Soc. Sym. 7:203-215.

Volk, E. C., D. M. Mortenson, and A. J. Wertheimer. 1993. Non-daily otolith increments and seasonal changes in growth of pink salmon (Oncorhynchus gorbuscha) population in Auke Bay, Alaska. Washington state Dept. of Fisheries, Olympia, Washington and National Marine Fisheries Service, Auke Bay, Alaska. Unpublished. Presented at the Fish otolith Research and Application symposium, South Carolina, January 1993. 
Volk, E. C., S. L. Schroder, J. J. Grimm, and H. S. Ackley. 1994. Use of a bar code symbology to produce multiple thermally induced otolith marks. Trans. Amer. Fish. Soc. 123:811-816.

Warren, E. E. 1971. Biology and water pollution control. W. B. Saunders Co., Philadelphia.

Wright, P. J., N. B. Metcalfe, and D. R. Rowe. 1993. The regulation of otolith increment formation in Atlantic salmon. SOAFD Marine Lab, Victoria RDI. Aberdeen AB9 8DB, Scotland, UK. Unpublished. Presented at the Fish otolith Research and Application Symposium, South Carolina, January 1993. 